Шлемко Ольга Дмитрівна, https://orcid.org/0000-0002-3431-4521 кандидат мистецтвознавства, дочент, заслужена артистка Украӥни,

Київський начіональний університет культури і мистеитв Київ, Украӥна olgateten@ukr.net

\title{
«ПРАХТИКОВАНИЙ ЖОВНІР» ГНАТА ХОТКЕВИЧА - НЕЗДІЙСНЕНА ПОСТАНОВКА ЛЕСЯ КУРБАСА
}

Мета статті - визначити проблематику та жанрово-стильові особливості п’єси Г. Хоткевича «Прахтикований жовнір», з'ясувати обставини участі

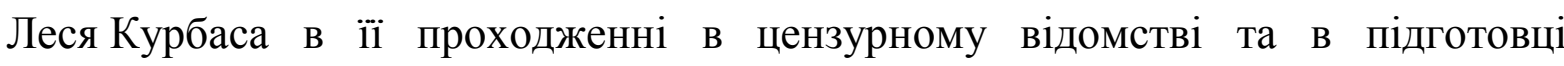
до постановки на сцені Гуцульського театру. Методологію дослідження 
становлять системний та соціокультурологічний підходи, а також такі методи: історико-біографічний, культурно-історичний, герменевтичний, соціологічний. Наукова новизна полягає у тому, що вперше в українському мистецтвознавстві з'ясовано проблематику, жанрово-стильові особливості та значення п’єси «Прахтикований жовнір», спробу іiі сценічного втілення Лесем Курбасом. Висновки. П'єсу «Прахтикований жовнір» (1912), написану гуцульською говіркою, за жанрово-стильовими ознаками можна означити як «сатиричну казку-комедію», створену в гуцульському стилі. Сюжет п’сси відображає пригоди бравого відставного жовніра - уособлення українського характерника, який вступає у боротьбу із силами зла і перемагає їх. У п’єсі порушено проблему запродування душі не лише окремої людини, а й всього народу. Дійові особи послуговуються гуцульською говіркою, що відображає особливості їхнього характеру, національності, світогляду, функціонального призначення і позбавляє уніфікації. Досвід акторської, режисерської, адміністративної роботи Леся Курбаса в Гуцульському театрі, прагнення поставити п’єсу «Прахтикований жовнір» загартували його як митця, розвинули творчі здібності, зануривши у стихію міфопоетичного світосприйняття гуцулів.

Ключові слова: п’єса; казка; гуцульська говірка; жанр; стиль; Жовнір; Г. Хоткевич; Лесь Курбас; Гуцульський театр.

Шлемко Ольга Дмитриевна, кандидат искусствоведения, доцент, заслуженная артистка Украины, Киевский наџиональный университет культуры и искусств, Киев, Украина

«Бывалый солдат» Гната Хоткевича - неосуществленная постановка Леся Курбаса

Цель статьи заключается в выявлении проблематики и жанровостилевых особенностей пьесы Г. Хоткевича «Бывалый солдат», выяснении обстоятельств участия Леся Курбаса в ее прохождении в цензурном ведомстве и в подготовке к постановке на сцене Гуцульського театра. Методологию исследования представляют системный и социокультурный подходы, а также такие методы: историко-биографический, культурно-исторический, герменевтический, социологический. Научная новизна заключается в том, что впервые в украинском искусствоведении выяснены проблематика, жанрово-стилистические особенности и значение пьесы «Бывалый солдат», попытка ее сценического воплощения Лесем Курбасом. Выводы. Пьесу «Бывалый солдат» (1912), написанную гуцульским говором, по жанровостилевым признакам можно обозначить как «сатирическую сказку-комедию», созданную в гуцульском стиле. Сюжет пьесы отображает приключения бравого 
отставного солдата - олицетворение украинского характерника, который вступает в борьбу с силами зла и побеждает их. В пьесе поднята проблема продажи души не только отдельного человека, но и всего народа. Действующие лица пользуются гуцульским говором, который отображает особенности их характера, национальности, мировоззрения, функционального назначения и лишает унификации. Опыт актерской, режиссерской, административной работы Леся Курбаса в Гуцульском театре, стремление поставить пьесу «Бывалый солдат», закалили его как художника, развили творческие способности, окунули в стихию мифопоэтического мировосприятия гуцулов.

Ключевые слова: пьеса; сказка; гуцульский говор; жанр; стиль; Солдат; Г. Хоткевич; Лесь Курбас; Гуцульский театр.

Shlemko Olga, Ph.D. in History of Arts, Associate Professor, Honored Artist of Ukraine, Kyiv National University of Culture and Arts, Kyiv, Ukraine

\section{"Battle-seasoned Soldier" by Hnat Khotkevich is Les Kurbas's unrealized staging}

The purpose of the article is to determine the issues and genre-stylistic particularities of G. Khotkevych's play "Battle-seasoned Soldier" and to find out the circumstances of Les Kurbas's participation in its passing through the department of the state censorship and in the preparation of its staging at the Hutsul theatre. Methodology of investigation consists of systemic and sociocultural approaches and includes such methods as historical-biographical, cultural-historical, hermeneutical and sociological. Scientific novelty of work consists in the fact that the author is the first person in the Ukrainian art history, who has found out the genre-stylistic particularities and significance of the play "Battle-seasoned Soldier" and Les Kurbas's attempt of its staging. Conclusions. G. Khotkevych wrote the play "Battle-seasoned" by the Hutsul dialect. According to the genre-stylistic features, it can be described as the "satirical fairy-tale comedy", created in the Hutsul style. The plot of the play reflects the brave retired soldier's adventures, the personification of the Ukrainian magician, who defeats the evil forces. The play is devoted to the problem of selling the personal soul to the Devil. Actors use the Hutsul dialect, which reflects the particularities of their character and worldview. Les Kurbas's experience of acting, directing, administrative work at the Hutsul theatre and his desire to stage the "Battle-seasoned Soldier", formed him as an artist, developed creative abilities and acquainted him with the mythical poetic world perception of the Hutsuls.

Key words: play; fairy tale; Hutsul dialect; genre; style; Soldier; Gnat Khotkevych; Les Kurbas; Hutsul Theatre. 
Постановка проблеми. Після утворення незалежної Української держави проблема збереження архаїчних традицій та мовного дивосвіту гуцулів, які $\epsilon$ важливим етноінтегруючим чинником, набула значної актуальності, вимагаючи освоєння багатої драматургічної спадщини Гната Хоткевича. Гуцульські твори митця заслуговують на сценічну інтерпретацію, зокрема п'єса «Прахтикований жовнір», філософською домінантою якої $\epsilon$ проблема насильницького запродування душі народу, нації. Християнка Крулева, що змирилась зі своєю нещасною долею і покірно зносить знущання поганського Круля, асоціюється із Гуцульщиною та Україною, а в глобальнішому вимірі iз тими слов'янськими народами, що перебували під гнітом Австро-Угорської та Російської імперій.

Аналіз останніх досліджень і публікацій. Про гуцульські п'єси Г. Хоткевича згадують у своїх публікаціях П. Арсенич, П. Будівський, I. Волицька, Р. Кирчів, А. Мельничук, Я. Партола, Ф. Погребенник, В. Стеф'юк, С. Чарнецький та ін., але п'єса «Прахтикований жовнір» досі не стала предметом зацікавлень ні театрознавців, ні літературознавців.

Першу публікацію гуцульських п'єс Г. Хоткевича здійснили М. Дзурак, Р. Марків, А. Вовчак, впорядкувавши та підготувавши до друку текст книжки «Неопубліковані гуцульські п’єси» (2005, с. 310), де вміщено також $\mathrm{i}$ «Прахтикованого жовніра». Однак це видання породило чимало запитань, оскільки поставлено під сумнів автентичність деяких надрукованих п’єс.

Про діяльність Леся Курбаса в Гуцульському театрі тією чи іншою мірою згадують Г. Хоткевич, М. Рудницький, Т. Водяний, Й. Гірняк, П. Хоткевич, Р. Пилипчук, М. Лабінський, В. Стеф'юк, М. Шудря, І. Волицька, П. Медведик, Ю. Бобошко, Н. Кузякіна, В. Шлемко, В. Ревуцький, П. Арсенич А. Болабольченко та ін., однак дослідники називають різні дати початку і завершення праці митця в Гуцульському театрі, по-різному описують його функціональні обов'язки.

Мета статті - визначити проблематику та жанрово-стильову специфіку п’єси Г. Хоткевича «Прахтикований жовнір», іiі внутрішню і зовнішню структуру; з'ясувати участь Леся Курбаса у їі проходженні в цензурному відомстві та підготовку до постановки на сцені Гуцульського театру; на підставі текстологічного аналізу з'ясувати історію тексту, питання авторства, часу, місця та обставин його створення, здійснити порівняння різних варіантів тексту.

Методологію дослідження становлять системний та соціокультурологічний підходи, а також такі методи: історико-біографічний (вивчено відносини «автор твір»), культурно-історичний (виявлено зв'язок п'єси з духовною і матеріальною культурою народу, соціальним середовищем), герменевтичний (здійснено інтерпретацію художнього тексту та осягнено його глибинний сенс), 
соціологічний (визначено соціальне спрямування п'єси). Також використано методологію праці В. Проппа «Морфология “волшебной сказки”...» (1998, с. 512) (з'ясовано функції дійових осіб).

Виклад основного матеріалу. Глибоке знання Г. Хоткевичем історії українського театру, розуміння соціальної та суспільно-політичної ситуації, значення для розвитку української культури фольклорної спадщини Гуцульщини, завдань та викликів, що постали перед українцями на початку ХХ ст., сприяло виробленню правильного підходу до формування репертуару та визначення надзавдання Гуцульського театру, який став мистецьким та етносоціокультурним феноменом не лише українського, але й світового театрального мистецтва.

Творчі стежки Леся Курбаса і Г. Хоткевича перетиналися неодноразово. Їхнє перше знайомство сталося у Львові найімовірніше у 1909 р. Саме тоді Г. Хоткевичеві судилося стати першим рецензентом дебютного виступу Леся Курбаса в ролі Каміла («Псотник» А. Коцебу) на сцені аматорського театру товариства «Сокіл».

Гуцульський театр, створений Г. Хоткевичем 1910 р. в гуцульському селі Красноїллі, займає у творчому житті Леся Курбаса особливе місце. М. Рудницький, у праці «В наймах у Мельпомени» (1963), зазначив: «Курбас провадив палкі розмови з Гнатом Хоткевичем. Тяжко було визначити, хто з них більше потребує один одного» $(1963$, с. 304). Г. Хоткевич пояснював Лесю Курбасу «як він уявляє собі новий театр, в якому гратимуть головно гуцули. Курбас уважно прислухався і не заперечував проти ще одного експерименту» (1963, с. 304).

Феномен Гуцульського театру полягає, насамперед, у генетичному зв'язку із традиційною культурою автохтонних гуцулів, унікальному поєднанні в репертуарі місцевої тематики та гуцульської говірки, формуванні трупи 3 місцевих народних професіоналів - носіїв фольклорних знань. Гуцульські актори могли блискуче відтворювати характери гуцулів, однак ролі негуцулів давались їм важко, тому такі ролі доручали Лесю Курбасу та О. Ремезу.

Репертуар Гуцульського театру, який складався із чотирьох п’єс - «Анін Ревізорчук» (виставлялась під назвою «Верховинці»), «Довбуш», «Гуцульський рік», «Непросте», відтворював літопис життя гуцулів у всіх його проявах; він містив коди етнонаціональної гуцульської ментальності, давав змогу гуцульським артистам виявити різні грані своїх талантів, ставши візитною карткою театру.

«Прахтикований жовнір» - п'ята п'єса Г. Хоткевича із циклу драматичних творів на гуцульську тематику, яку він завершив на початку $1912 \mathrm{p}$. Ф. Погребенник вважає датою написання цієї драми 1911 р. (1966, т. 1, с. 19). 
Незважаючи на запозичення деяких сюжетних колізій із гуцульських народних казок, драму «Прахтикований жовнір» цілком оригінальний, самобутній твір, 3 цікавим та актуальним ідейним задумом, динамічним розгортанням подій, соціально-загостреним змістом, колоритною гуцульською говіркою.

У фонді Г. Хоткевича в Центральному державному історичному архіві України у Львові зберігаються два недатовані рукописні варіанти п'єси «Прахтикований жовнір», перший 3 яких означений як «Казки народні в V діях» (Ф. 688. Оп. 1. Спр. 70. Арк. 2-33), а другий - «Гуцульські казки в IV діях» (Ф. 688. Оп. 1. Спр. 70. Арк. 35-80), а також недатований рукописний кіносценарій «Храбрый солдат» (Ф. 688. Оп. 1. Спр. 143. Арк. 1-48). У фонді драматичної цензури Санкт-Петербурзької державної театральної бібліотеки зберігається третій недатований машинописний варіант цієї п'єси під назвою «Храбрый солдат», означений як «мотивы гуцульских сказок в IV действиях» (Хоткевич, Спр. 51926. Арк. 44). На титульній сторінці п’єси під вердиктом: «К представлению дозволено. С.-Петербург. 29 августа 1913 г.» стоїть підпис цензора драматичних творів. Чотири дії всіх трьох варіантів з незначними відмінностями $є$ ідентичними. Водночас у третьому машинописному варіанті п'єси на початку подається російською мовою короткий виклад змісту кожної дії (у другому варіанті аналогічний виклад змісту закреслено). Порівняльний аналіз свідчить, що первісним був саме перший варіант п'єси. Почеркознавчий аналіз дозволив встановити, що перший варіант п'єси написаний власноручно Г. Хоткевичем.

Працюючи над п'єсою, драматург вивчав фольклорну спадщину, пов'язану із жовнірською темою, цікавився військовою термінологією. На його прохання Л. Гарматій у листі від 21.01.1912 р. детально описав німецькою мовою військові команди та інші найбільш поширені в австрійській армії вислови (Ф. 688. Оп. 1. Спр. 307. Арк. 118-119).

Мова дійових осіб п'єси, позначена образними фразеологізмами,важливий засіб характеристики персонажів. Жовнір та інші автентичні гуцули послуговуються виключно гуцульською говіркою, що відображає особливості їхніх характерів, світоглядів, моральних засад. Мова негуцулів теж гуцульська, але вона має певну специфіку залежно від національності та соціального становища персонажів. Представники потойбіччя (дідьки, ангели, Смерть) так само розмовляють по-гуцульськи. Навіть Круль (король) і той розмовляє гуцульською говіркою. Натомість ремарки написані українською літературною мовою. У такий спосіб драматург наголошує, що гуцульська говірка годиться не лише для хлопа; нею можуть розмовляти навіть королі. Жовнір час від часу співає гуцульських пісень, що підкреслює його жартівливість, дотепність, впевненість і надає п’єсі гуцульського колориту. 
Драма «Прахтикований жовнір» так і не була поставлена в Гуцульському театрі, хоча Лесь Курбас готувався до їі сценічного втілення. У листі до Г. Хоткевича від 09.04.1912 р. він, зокрема, повідомляв: «Щодо примірника (п’єси «Прахтикований жовнір» - $О$. $Ш$.), то тов. Корнило Заклинський $[\ldots]$ передав його мені ще як ми були у Львові, і він тепер у мене» (Спр. 10880. Арк. 4). Отже, під час гастролей Гуцульського театру 04.03.1912 р. у Львові п'єса вже була написана, а завершив іiі Г. Хоткевич, очевидно, напередодні виїзду на початку лютого 1912 р. з Галичини до Києва.

Сюжет «Прахтикованого жовніра» побудований на пригодах бравого Жовніра, котрий повертається після служби в армії. На початку п'єси з монологу Жовніра довідуємося, що звати його Василь. Однак у тексті твору він фігурує як Жовнір, тобто як певний образ-символ. Також відомо, що він гуцул, сирота, не має ні сім’ї, ні хати. Хоча драматург не вказав місце дії, із реплік дійових осіб стає зрозуміло, що це Гуцульщина за австрійських часів. Казкові персонажі драми позбавлені деяких звичайних людських реакцій на зовнішні подразники і сприймаються швидше як символи-архетипи.

Жовнір стає свідком ганебної сцени, коли жиди-лихварі під час похоронної процесії б'ють небіжчика-християнина за те, що той заборгував їм ще за життя 34 леви. У кишені Жовніра виявилось саме 34 леви, і він віддає ї лихварям, порятувавши від наруги зовсім незнайомого йому небіжчика. У небіжчикові персоніфіковано «тінь» Жовніра, яка «репрезентує тут нереалізовану сторону внутрішнього життя героя, потенційні якості, які ще не стали органічною частиною його характеру і вчинків» (Франц, 1998, с. 142). Заплативши лихварям чужий борг, Жовнір тим самим передав частину своєї енергії «тіні», перетворивши іï на свого друга. Незабаром «тінь» трансформується, з'явившись на вищому духовному рівні у вигляді трьох старців, які є «Божими слугами».

Успішно пройшовши випробування, Жовнір отримав від старців як винагороду чарівні карти і тайстру, а також здатність примусити будь-кого сидіти і не вставати. Старці постають як «помічники-дарителі», що характерно для чарівних казок.

Жовнір довідується, що в одній країні, яка знаходиться за трьома морями і лісом, править жорстокий поганський круль Кокус, який знущається над своєю жоною - християнкою Крулевою і підневільним християнським людом. Сила Круля таїться у християнці Крулевій, яка перебуває в неволі через те, що душу без іiі волі запродали дияволові. Одержимий благородними почуттями, Жовнір вирушає в дорогу, щоб покарати жорстокого Круля, визволити з неволі Крулеву, а заодно - і весь пригноблений народ. 
Конфлікт п'єси набуває яскраво вираженого соціально-політичного забарвлення у зв'язку з тим, що християнка Крулева, яка смиренно зносить знущання поганського Круля, асоціюється із Гуцульщиною та Україною, котрі перебували під гнітом Австро-Угорської та Російської імперій. Гуцульському театрові також довелось діяти в умовах агресивного середовища Австро-Угорської монархії, намагань всіляко обмежити його діяльність.

Щоб звільнити Крулеву, Жовнірові за велінням Круля довелось провести одну ніч у цимбрі, де на нього чекало найнебезпечніше випробування. Однак Жовнір здобуває перемогу над Дідьком, перегравши його в чарівні карти і заманивши в чудодійну тайстру. Коли ж зграя чортів благає Жовніра відпустити їхнього родича, то він погоджується за умови, якщо ті приженуть сюди Круля. Тож до ніг Жовніра покотилася крулівська корона, а переляканого на смерть Круля «стинає» Смерть. Отже, зло покарано. Власне, сцена перемоги героя над Дідьком і покарання Круля є кульмінаційним моментом дії казкової драми.

Безстрашний Жовнір устиг ще й добряче перелякати представників потойбічного світу, змусивши сісти і не вставати саму Смерть. Визволити Смерть злетілась велика кількість ангелів, оскільки люди і все живе перестало гинути. Врешті, Жовнір змилостивився і відпустив Смерть, але з тією умовою, що вона прийде за ним тоді, коли він сам ii покличе. Завершується дія драми традиційною для казки розв'язкою - одруженням Жовніра із чарівною Крулевою та обранням його крулем.

У п’ятій дії твору відображено новий етап пригод Жовніра-круля. Остання дія - це міні-п'єса, що містить експозицію, зав'язку, кульмінацію і розв'язку. Між четвертою і п'ятою діями значний часовий розрив, заповнений правлінням Жовніра-круля. Коли Жовнірові врешті надокучила одноманітність земного життя і набридло бути крулем, він відправляється у потойбічний світ. Пекло і рай, які утворюють потойбічний світ, знаходяться поряд в одному просторі іє альтернативою земному світові. Опинившись у пеклі, Жовнір одразу ж виявив бажання будувати там церкву, що викликало переполох серед чортів, котрі почали вмовляти Жовніра покинути пекло, обіцяючи дати на дорогу грошей. Але його цікавили не гроші, а душі грішників. Пекло сприймається не як потойбічний, а цілком реальний світ, де мучаться і душі злочинців, і безневинних людей. Для поневолених українців реальне життя було часто гірше пекла і навіть з'ява, як за помахом чарівної палички, власної держави не призвела до звільнення їхніх душ від рабського стану.

Жовнір розумів, що в пекло несправедливо запроторено не лише душу християнської Крулеви, а й багато інших безневинних душ. Граючи в чарівні карти з дідьками на душі грішників, Жовнір раз у раз виграє, і звільнені душі 
почали масово покидати пекло. Жовнірові вдалося виграти в найстаршого чорта головний атрибут його влади - Гак, після чого в пеклі вдарив грім і почувся стогін всіх чортів. Влада пекла похитнулася, але чорти запропонували віддати Жовнірові замість Гака душу його покійної дружини.

Автор проводить думку: позбавивши пекельні сили Гаку - символу безмежної сатанинської влади - можна знищити й саме пекло. Однак драматург свідомо не дає героєві заволодіти Гаком, оскільки навіть такому «прахтикованому» жовнірові не під силу самому знищити пекло як уособлення світового зла. Завершується дія сакраментальною реплікою Жовніра: «Ширше браму отворєй!» (Ф. 688. Оп. 1. Спр. 70. Арк. 33). Хоткевич використав оригінальний драматургічний хід, вкладаючи у вуста героя, який із захованою у чарівній тайстрі Крулевою прямує через браму до раю, пісню про те, що навіть святі його звідти прогнали. Такий прийом сприяв уникненню показу сцени перебування Жовніра в раю та його вигнання звідти. Отже, пригоди Жовніра ще не завершились і триватимуть, допоки у світі буде неправда і кривда, доки його народ перебуватиме в ярмі.

У Жовніра, як казкового героя-шукача і визволителя, відсутня внутрішня боротьба, його душу не терзають докори чи сумніви, а тому він безстрашно поринає у вир драматичної боротьби і виходить з неї переможцем. У досягненні своєї мети йому допомагають не лише магічні засоби, а i власна воля, кмітливість, одержимість. Зовнішня контрдія представлена такими персонажами, як дідьки, пани, жиди, Йойна, Сура, Круль, Смерть, з котрими герой змушений вступати в конфлікт.

Розв'язка основного конфлікту п'єси обумовлена і об'єктивним чинником - вимогами до розвитку казкового сюжету і композиції драматичного твору, і суб'єктивним - світоглядом та волею драматурга, який утілив у безсмертному Жовнірові ідею незнищенності духу українського народу. В тому, що Жовнір може жити стільки, скільки захоче сам, закладено глибинний філософський зміст: доля Жовніра, як і доля всього народу, нації залежить від сили їхнього духу, волі і цілеспрямованості, бажання жити і стверджуватись.

У гуцульському Жовнірові вгадуються риси загадкового українського козака Мамая - характерника, воїна, шукача правди і справедливості. Жовнір також утілює космологічну велич, він - виразник українського менталітету. Від початку XX ст., часу написання Г. Хоткевичем п'єси «Прахтикований жовнір», подібного за тематикою та ідейно-філософським звучанням драматичного твору в Україні так і не з'явилося.

3 огляду на те, що модель світу митця є значною мірою віддзеркаленням його власного «Я», можна провести біографічні та художні паралелі 
у «Прахтикованому жовнірі»: це насамперед постійне перебування Г. Хоткевича і Леся Курбаса на вістрі таких межових ситуацій, як вибір, смерть, боротьба, страждання, відчай, самотність. Зокрема, Лесь Курбас незадовго перед вступом до Гуцульського театру намагався накласти на себе руки, а Г. Хоткевич несподівано приймає рішення повернутися з Галичини додому на Наддніпрянщину, де його очікує арешт i в’язниця. Сам Г. Хоткевич так пояснює свій переїзд: «Душевний стан у мене був такий, що ладен був їхати - хоч до чорта в зуби. Та більш-менш до чорта в зуби я і їхав» $(1928$, т. 1 , c. 26). Якщо у 1906 р. письменник тікав від переслідувань з ненависного російського «пекла» в конституційний австрійський «рай», то вже через 6 років тікав 3 цього «раю», що перетворився для нього на пекло. Жовнір так само не зміг бути довго в раю, а тому й подався в пекло. В Радянській Україні Г. Хоткевичу не вдалося відродити Гуцульський театр, як не вдалося здійснити чимало із своїх грандіозних задумів. Тут на відміну від міфологічного бестіарію, виведеного в гуцульських п'єсах, існував реальний комуністичний бестіарій. То ж довелось зізнатись і у «шпигунстві», і у всіх інших «гріхах» перед радянською владою і загинути в катівнях НКВС.

Лесь Курбас, вирвавшись із задушливого мороку Галичини, що здавалась йому ледь не пеклом, потрапив до Києва як до «небесного града», тобто у рай. Згодом митець повірив у можливість побудови «комуністичного раю». Так само, як Жовнір, котрий вирішив збудувати у пеклі церкву, Лесь Курбас почав будувати в тодішньому «тоталітарному пеклі» духовний храм у вигляді модерного національного театру. Згодом його запроторили в концтабори і знищили. Однак і Г. Хоткевич, і Лесь Курбас так само, як і Жовнір, виявилися безсмертними: дух цих національних велетів і досі надихає митців, а їхній творчий доробок є животворним і нетлінним.

Стосовно жанрової приналежності п’єси «Прахтикований жовнір», то, зважаючи на казковий сюжет, використання сатиричних засобів, за допомогою яких різко висміюються соціальні та суспільно-політичні вади, зображуються смішні події й персонажі, іiі можна означити як «сатиричну казку-комедію».

Особливий вплив на формування стилю гуцульських п'єс та підготовлених на їх основі вистав Гуцульського театру мав індивідуальний художній стиль Г. Хоткевича. Однак осягнути цей стиль можна лише за умов знання особливостей характеру i чіткої життєвої позиції митця. Як пасіонарна особистість, Г. Хоткевич відчував свою особливу місію на ниві української культури, а тому, долаючи численні перешкоди, намагався встигнути зробити якнайбільше iз наміченого. Не відкидаючи кращих здобутків реалістичного 
напряму в українському театрі, Г. Хоткевич творчо їх розвивав, шукав нових виражальних засобів. П'єси на гуцульську тематику, у яких поєдналися традиційний реалізм, романтизм, неоромантизм, що знайшли міцне підгрунтя у фольклорній творчості гуцулів, важко втиснути в рамки існуючого на той час стилю.

Важливий стилетвірний фактор - гуцульська говірка; вона стала також важливим дійовим засобом вияву глибинної сутності вистав Гуцульського театру. Г. Хоткевич вважав, що гуцульська говірка повинна відіграти значну роль у формуванні української літературної мови, збагатити iï та урізноманітнити. Лише опанувавши тамтешні мовленнєві жанри в побутовому, ритуальному, гумористичному та інших дискурсах, Г. Хоткевич приступив до написання гуцульських п’єс. Митець навчився не лише вільно розмовляти й писати говіркою, але й почав навіть мислити по-гуцульськи. На особливостях мови гуцульських п'єс відбився також ідіостиль та ідіолект самого Г. Хоткевича. Він довів, що гуцульська говірка може бути не лише елементом стилізації, а цілком самостійною, художньо самодостатньою системою.

Молодий 23-літній Лесь Курбас з'явився в Гуцульському театрі, маючи чималий життєвий і мистецький досвід. У його творчому і життєвому доробку значилися: навчання у Віденському та Львівському університетах; відвідування драматичної школи при Віденській консерваторії; виступи як актора на сцені аматорського театру спортивного товариства «Сокіл»; праця актором і режисером у студентському театрі; короткострокове ув'язнення як учасника студентського віча, під час якого було вбито одного з лідерів українського студентства Адама Коцка; призов до австрійської армії та демобілізація за кілька місяців за станом здоров'я.

У дослідників немає одностайності щодо режисерської діяльності Леся Курбаса в Гуцульському театрі. Однак не варто і перебільшувати його роль у діяльності Гуцульського театру, як це зробив, наприклад, Ю. Бобошко, стверджуючи, що митець, перебуваючи на посаді одного з режисерів цього театру, нібито «ставить найхарактерніші свої вистави «Гуцульський рік», «Непросте», «Прахтикований жовнір», «Довбуш» (1987, с. 14). Натомість документально підтверджено, що всі згадані твори написав і поставив Г.Хоткевич, окрім п’єси «Прахтикований жовнір». Водночас не виключається можливість залучення до деяких постановок Леся Курбаса, але не як самостійного режисерапостановника. 
Г. Хоткевич через свою зайнятість не міг виїздити з Гуцульським театром у гастрольні подорожі, тому він підшукав на посаду директора театру Олексу Ремеза, політичного емігранта із Наддніпрянської України, який вже мав досвід праці в Театрі товариства «Руська бесіда». За собою Г. Хоткевич залишив посаду «начального» директора, тобто здійснював загальне керівництво. Адміністративно-мистецькому проводові в особі Г. Хоткевича, О. Ремеза, Леся Курбаса, Й. Гулейчука вдалося налагодити чіткий механізм діяльності Гуцульського театру в умовах хронічного безгрошів'я та постійних переїздів.

У Гуцульському театрі Лесь Курбас виконував функції актора, режисера, передовика (організатора глядача). Обов'язки керівника театру він міг виконувати лише за умов відсутності з якихось причин О. Ремеза. Режисерська праця Леся Курбаса полягала здебільшого у підтриманні цілісності вистав, уведені на ролі окремих акторів, дотриманні творчої дисципліни. Постановка в Гуцульському театрі п’єси Г. Хоткевича «Прахтикований жовнір» так і залишилася нездійсненним задумом Леся Курбаса.

Важливу інформацію про Леся Курбаса висвітлюють листи О. Ремеза до Г. Хоткевича. Так, у лютому 1912 р. під час гастрольної подорожі по Галичині, О. Ремез повідомляв Г. Хоткевича, що «Курбас помагає, але хорує, від того і дістає відразу» (Спр. 6659. Арк. 2), тобто Лесь Курбас допомагає організовувати вистави. У листі від 13 (25) квітня 1913 р. О. Ремез повідомляє Г. Хоткевича, який проживав на той час у Києві: «А от Курбас вінчає чоло лаврами. Дуже гарний і інтелігентний з нього актор виходить. От замість того, щоб пристроювати там Порайка, який, не во гнів йому кажучи, сам не знає, чого хоче, а й ледачий трохи, пристройте в Садовського Курбаса. Він тут зіпсується геть. Да й сам він хоче втікати до Варшави [...] Заручіть Садовському, що се добра сила, молода, інтелігентна, та відпишіть Курбасові, і він поїде» (Спр. 6721. Арк. 4), - продовжує О. Ремез умовляти Г. Хоткевича. Отже цілком можливо, що за інших обставин Лесь Курбас міг би стати реформатором не українського, а польського театру.

Перший прихід Леся Курбаса в Гуцульський театр відбувся в останній декаді травня 1911 р., але ще не як «штатного» працівника, а як «разового гастролера», для заміни хворого М. Сінітовича - виконавця ролі Антося Ревізорчука у виставі «Верховинці». Йосип Гірняк у своїх спогадах виразно змалював своє перше враження від гастролей Гуцульського театру в Тернополі, які відбулися 23 травня 1911 р., та від молодого Леся Курбаса, якого спочатку 
випадково побачив на Панській вулиці біля рекламної афіші місцевого кінотеатру. На вечірній виставі «Верховинці» Йосипа глибоко вразила блискуча гра Леся Курбаса у ролі Антося Ревізорчука (1982, с. 487). Другий прихід Леся Курбаса в цей самобутній театр відбувся наприкінці 1911 р. і тривав по квітень 1912 p.

У лютому 1912 р. Г. Хоткевич виїхав з родиною до Києва, прагнучи підготувати гастролі Гуцульського театру на Наддніпрянщині, в Москві та інших містах Російської імперії. По завершенні гастролей Гуцульського театру на початку квітня 1912 р. Лесь Курбас, перебуваючи вдома у Старому Скалаті, що на Тернопільщині, постійно тримав на контролі ситуацію, пов’язану з підготовкою до гастролей. Він листувався 3 Г. Хоткевичем, Й. Стадником, Й. Гулейчуком, О. Ремезом і одразу ж після Великодня планував поїхати в Красноїлля, щоб підібрати нових артистів і провести репетиції вистав. Про наміри Леся Курбаса поставити п’єсу «Прахтикований жовнір» свідчать листи до Г. Хоткевича у Київ.

У листі до Г. Хоткевича від 3.04 .1912 р. Лесь Курбас розмірковує над пропозицією Г. Хоткевича щодо призначення Настуні Минайлюк на роль Королевої у виставі «Прахтикований жовнір». Лесь Курбас запитує письменника: «І ще одно: кому Ви призначили роль королевої? Пишете «Слена». Чи це має бути Настуня Міняйлюківна? Мабуть, «Єлена» з Гуцульського року?» (Спр. 10879. Арк. 2). Як бачимо, Лесь Курбас практично не впливав на розподіл ролей у згаданій постановці, які здійснював Г. Хоткевич.

У наступному листі від 9.04.1912 р. Лесь Курбас запитує: «Якщо треба Вам подавати його (примірник п’єси «Прахтикований жовнір» - О.Ш.) до російської цензури, то прошу написати мені, а я його якось перепишу і надішлю Вам оригінал. До Красноїлі думав я їхати на сьому тижні, але Ваше «не знаю як ліпше» і «є ще час» забило мені цьвяха в голову. Бо й справдіякщо справа має протягнутись на місяць-півтора, то там-таки не буде що робити тепер. А поки я не знатиму, як Ви думаєте урегулювати матеріяльний бік діла, кому Ви думаєте повернути гроші зараз, а кому ще ні [...] Поки я того всего не знаю, то не маю ніяких підстав, на яких міг би організувати, т[о] є[сть] стисло - вербувати [...] Тому, думаю, - найкраще буде, як я зажду тут, у себе дома, аж поки Ви, зміркувавши, що в Росії поладналось усе в нашу користь не дасте мені знаку - їхати. I ще прошу мені описати ті «основи вербунку» (Спр. 10880. Арк. 4). У цьому листі Лесь Курбас натякає про власний намір 
очолити гастрольну поїздку Гуцульського театру в Росію. Це допомогло б йому вирватися із задушливої атмосфери Галичини i пов'язати свою творчу діяльність із Наддніпрянською Україною.

В останньому відомому нам листі Леся Курбаса 3 Галичини до Г. Хоткевича, датованому 12.04.1912 р., митець подає короткий виклад листа Й. Гулейчука з Красноїлля, який, зокрема, повідомляє: «Найшов багато нових, гарних хлопців, ще бракує дівчат, бо з старих здаєси лишитси кілька. Не знаю чи не взяти яких панєн тих, що зголошувались, аби лиш по гуцульськи перебрались» (Спр. 6718. Арк. 4) Лесь Курбас одразу коментує: «[...] мені здаєсь, що це було б не доцільно їх брати» (Спр. 6718. Арк. 4). Таке коментування свідчить про розуміння Лесем Курбасом того, що унікальність Гуцульського театру криється, насамперед, у самобутності автентичних гуцулів.

У цьому листі Лесь Курбас також зазначає: «І взагалі - мені самому було б дуже важно і цікаво знати, чи є вже тепер яка-небудь приблизна певність щодо часу нашого виїзду до Росії. А якщо $є$, то коли мав би цей історичний факт задивувати світ?» (Спр. 6718. Арк. 4). Далі Лесь Курбас наголошує: «Якщо самі що-небудь про це знаєте, то при нагоді напишіть, бо мені треба б поладнати деякі домашні справи, а спосіб їх поладнання якраз зависить від часу мого виїзду [...] Ах, ще кілька слів про «Прахт[икованого] жовніра». Оскільки знаю, то всяка п’єса мусить вилежатись в цензурі щонайменше два місяці, поки iii цензор за один день не полагодить. 3 огляду на «поспіх» Стадника, не знаю я, як воно готово вийти. Як я був колись в Драматичній комісії Студ[ентського] Союза, то ми давали до цензури, що там треба було, а потім один ходив і все докучав цензорові, так що цензурований примірник одержували за місяць, а не за два. Раз дістали все - готове - за 3 тижні. Отож, думаю, - як їхатиму до Красноїлї, то поїду навмисне на Львів, і там або сам, або ким впливовійшим штурмуватиму цензора, до поспіху наганяти[му]. Але, може, Стадник і без того швидше одержує п’єси з цензури, яко фірма, а, по друге, може й не треба дуже спішитись?» Насамкінець Лесь Курбас ледь не волає: «Чекаю знаку од Вас з тугою, бо вдома скучно страшно - от Поділля. Хотів би вже в гори їхати. Страх як хотів би. А передчасом їхати, може, не «політично» (Спр. 6718. Арк. 4). Отже, в цей час Лесь Курбас спілкується 3 керівником Театру товариства «Руська Бесіда» Й. Стадником 3 приводу подачі до цензурного відомства Хоткевичевої п’єси «Прахтикований жовнір». До речі, канцелярія Головного Управління у справах друку в Петербурзі повідомила Г. Хоткевича листом від 05.09.1913 р. про дозвіл цензури на показ вистави «Прахтикований жовнір». 
Однак, не дочекавшись від Г. Хоткевича позитивної відповіді, або й дізнавшись про його арешт, Лесь Курбас, очевидно, не бачив за тих умов перспективи подальшого існування Гуцульського театру, а тому змушений був шукати інший варіант застосування свого творчого потенціалу. Тож з червня 1912 р. митець уже в Руському народному театрі товариства «Руська бесіда», де швидко зарекомендував себе як талановитий, різноплановий актор, продовживши сімейну традицію, започатковану своїми батьками - талановитими галицькими акторами Степаном та Вандою Яновичами.

Уже в радянський час Г. Хоткевич не раз звертався до керівника театру «Березіль» Леся Курбаса із проханням поставити п’єсу гуцульською говіркою (1966, т. 2, с. 574-575). Відомо, що Лесь Курбас збирався поставити на сцені цього театру драму Г. Хоткевича «Довбуш». Можливо, він також прагнув втілити в життя свою давню мрію щодо постановки п'єси Г. Хоткевича «Прахтикований жовнір», оскільки в листі до Г. Хоткевича від 01.11.1926 р. просив передати «гуцульські п’єси» (Спр. 6722. Арк. 1).

Наукова новизна. На основі неспростовних фактів уперше в українському мистецтвознавстві з'ясовано проблематику, жанрово-стильову специфіку та значення п’єси Г. Хоткевича «Прахтикований жовнір», спробу iii сценічного втілення Лесем Курбасом на сцені Гуцульського театру, уточнено деякі факти творчої біографії митця, спростовано недостовірну інформацію.

Висновки. Отже, п’єсу «Прахтикований жовнір» (1912), написану гуцульською говіркою, у дискурсі поєднання ідіолекту та ідіостилю Г. Хоткевича, за жанрово-стильовими ознаками можна означити як «сатиричну казку-комедію». Сюжет драми грунтується на народних казках, відображаючи пригоди бравого відставного Жовніра - уособлення українського характерника, який вступає в боротьбу із земними та надприродними силами зла і їх перемагає. У творі порушується проблема запродування душі не лише окремої людини, але й усього народу.

Г. Хоткевич уперше в українській драматургії створив цикл драм гуцульською говіркою і в такий спосіб «законсервував» для наступних поколінь мовний дивосвіт гуцулів. У п’єсі «Прахтикований жовнір» дійові особи (люди і представники потойбічного світу) послуговуються гуцульською говіркою, що відображає особливості їхніх характерів, національності, світоглядів, моральних засад, функціонального призначення, унеможливлюючи уніфікацію.

Досвід акторської, режисерської, адміністративної роботи Леся Курбаса в Гуцульському театрі, прагнення поставити п’єсу «Прахтикований жовнір», 
загартували його як митця, розвинули творчі здібності, занурили у стихію міфопоетичного світосприйняття гуцулів та їхньої фольклорної спадщини, сприяли формуванню образного мислення. Подальша доля Г. Хоткевича і Леся Курбаса свідчить про те, що, відчуваючи свою особливу місію на ниві української культури, вони вели себе так само безстрашно i мужньо, як і «прахтикований» Жовнір; завдяки своїй титанічній праці та безцінному творчому доробку, ці митці виявилися такими ж безсмертними.

\section{Бібліографічні посилання}

1. Бобошко Ю. М. Режисер Лесь Курбас. Київ : Мистецтво, 1987. 200 с.

2. Гарматій Л. [Лист до Г. Хоткевича]. 21 січ. 1912 р. // Центр. Держ. істор. архів України у Львові (далі - ЦДІА України у Львові). Ф. 688. Оп. 1. Спр. 307. Арк. 118-119.

3. Гірняк Й. Спомини. Нью-Йорк : Сучасність, 1982. 487 с.

4. Курбас Л. [Лист до Г. Хоткевича]. 3 квіт. 1912 р. // Музей театрального, музичного та кіномистецтва України (далі - МТМК України). Від. рукоп. фондів. Архів Леся Курбаса. Спр. 10879. 2 арк.

5. Курбас Л. [Лист до Г. Хоткевича]. 9 квіт. 1912 р. // МТМК України. Від. рукоп. фондів. Архів Леся Курбаса. Спр. 10880. 4 арк.

6. Курбас Л. [Лист до Г. Хоткевича]. 12 квіт. 1912 р. // МТМК України. Від. рукоп. фондів. Архів Г. Хоткевича. Спр. 6718.4 арк.

7. Курбас Л. [Лист до Г. Хоткевича]. 1 листоп. 1926 р. // МТМК України. Від. рукоп. фондів. Архів Г. Хоткевича. Спр. 6722. 1 арк.

8. Погребенник Ф. Гнат Хоткевич. Хоткевич Г. Твори : у 2 т. Київ : Дніпро, 1966. T. 1. C. 5-31.

9. Пропп В. Я. Морфология «волшебной» сказки. Исторические корни волшебной сказки. Москва : Лабиринт, 1998. 512 с.

10. Рахунок Гаврила Гарасим'юка для дирекції Гуцульського театру (п. Олекси Ремеза) за зібрані гроші від 8.XII.[1]911 р. по 8.ІІ.[1]912 // ДМТМК України. Від. рукоп. фондів. Архів Г. Хоткевича. Спр. 6659. 2 арк.

11. Ремез О. [Лист до Г. Хоткевича]. 13 (25) квіт. 1913 р. // МТМК України. Від. рукоп. фондів. Архів Г. Хоткевича. Спр. 6721. 4 арк.

12. Рудницький М. В наймах у Мельпомени. Київ : Мистецтво, 1963. 344 с.

13. Франц М.-Л. Психология сказки. Толкование волшебных сказок. Психологический смысл мотива искупления в волшебной сказке. Санкт Петербург : Б. С. К., 1998. 360 с. 
14. Хоткевич Г. [Театр гуцульський]. Твори : у 2 т. / упоряд., вступ. ст. та приміт. Ф. Погребенника. Київ : Дніпро, 1966. Т. 2. С. 539-578.

15. Хоткевич Г. «Храбрый солдат» : мотивы гуцульских сказок» : пьеса в 4 действиях // Санкт-Петербургская государственная театральная библиотека. Фонд драматической цензуры. Спр. 51926. 44 арк.

16. Хоткевич Г. «Прахтикований жовнір» : п’єса в 4 діях // ЦДІА України у Львові. Ф. 688. Оп. 1. Спр. 70. Арк. 35-80.

17. Хоткевич Г. «Прахтикований жовнір» : п’єса в 5 діях // ЦДІА України у Львові. Ф. 688. Оп. 1. Спр. 70. Арк. 2-33.

18. Хоткевич Г. «Храбрый солдат» : кіносценарій у 4 діях // ЦДІА України у Львові. Ф. 688. Оп. 1. Спр. 143. Арк. 1-48.

19. Хоткевич Г. Моя автобіографія. Хоткевич Г. Твори : у 8 т. Харків: Кооперативне видавництво «Рух», 1928. Т. 1. С. 5-36.

20. Хоткевич Г. Неопубліковані гуцульські п’єси. Луцьк : Терен, 2005. 310 с.

\section{References}

1. Boboshko, Iu. (1987). Les Kurbas, a Director. Kyiv: Mystetstvo.

2. Harmatii, L. (1912, January 21). Letter to G. Khotkevych, Central State Historical Archive of Ukraine in Lviv, fund 688, case 307, pp. 118-119.

3. Hirniak, I. (1982). Memories, Suchasnist, New York, 487 p.

4. Kurbas, L. (1912, April 3). Letter to G. Khotkevych, The Museum of Theatrical, Musical and Cinematographic Art of Ukraine, Manuscript of Les Kurbas, fund 688, case 10879 , p. 2.

5. Kurbas, L. (1912, April 9). Letter to G. Khotkevych, The Museum of Theatrical, Musical and Cinematographic Art of Ukraine, Manuscript of Les Kurbas, case 10880, p. 4.

6. Kurbas, L. (1912, April 12). Letter to G. Khotkevych, The Museum of Theatrical, Musical and Cinematographic Art of Ukraine, Manuscript of G. Khotkevych, case 6718, p. 4. 7. Kurbas, L. (1926, November 1). Letter to G. Khotkevych, The Museum of Theatrical, Musical and Cinematographic Art of Ukraine, Manuscript of G. Khotkevych, fund 688, case 6722, p. 1.

8. Pohrebennyk, F. (1966). Gnat Khotkevych, G. Khotkevych, Selected works: in 2 vol. Vol. 1. Kyiv: Dnipro, pp. 5-31.

9. Propp, V.Ya. (1998). Morphology “magic” fairy tale. Historical roots of a fairy tale. Moscow: Labirint.

10. The Bill of Havryla Herasymiuk to the Administration of the Hutsul Theatre, (Mr. Oleksa Remez) for the collected money from 8.XII.[1]911 p. till 8.II.[1]912, 
The Museum of Theatrical, Musical and Cinematographic Art of Ukraine, Manuscript of G. Khotkevych, case 6659, p. 2.

11. Remez, O. (1913, April 13 (25)). Letter to G. Khotkevych, The Museum of Theatrical, Musical and Cinematographic Art of Ukraine, Manuscript of G. Khotkevych, case 6721, p. 4.

12. Rudnytskyi, M. (1963). The Hired by Melpomene. Kyiv: Mystetstvo.

13. Frants, M.-L. (1998). Psychology of Fairy Tales. Interpretation of Magic Fairy Tales. Psychological Sense of the Atonement in the Fairy Tale. SPb: B.S.K.

14. Khotkevych, G. (1966) "Hutsul Theatre", in Pohrebennyk, F. (Ed.), Works: in 2 vol. Vol. 2. Kyiv: Dnipro, pp. 539-578.

15. Khotkevych, G. "Brave Soldier": motifs of the Hutsul Fairy Tales: Play in 4 Acts, Saint Petersburg State Theatrical Library, Fund of Drama Censorship, case 51926, p. 44.

16. Khotkevych, G. "Battle-seasoned Soldier": Play in 4 Acts, Central State Historical Archive of Ukraine in Lviv, fund 688, description 1, case. 70, pp. 35-80.

17. Khotkevych, G. "Battle-seasoned Soldier": Play in 5 Acts, Central State Historical Archive of Ukraine in Lviv, fund 688, description 1, case. 70, pp. 2-33.

18. Khotkevych, G. "Brave Soldier": cinema screen in 4 Acts, Central State Historical Archive of Ukraine in Lviv, fund 688, description 1, case. 7143, pp. 1-48. 19. Khotkevych, G. (1928). "My autobiography", Khotkevych, G. Works: in 8 vol. Vol. Kharkiv: Korporatyvne vydavnytsvo "Rukh", pp. 5-36.

20. Khotkevych, G. (2005). Unpublished Hutsul Plays, Lutsk: Teren.

(С Шлемко О. Д., 2018

Стаття надійила до редакиії 22.03.2018 